\title{
P.0. ЗОГРАБ’ЯН
}

\section{ЗАСТОСУВАННЯ АНТИОКСИДАНТІВ ДЛЯ ЛІКУВАННЯ ХРОНІЧНОЇ ДИСФУНКЦІЇ НИРКОВОГО АЛОТРАНСПЛАНТАТА}

\section{R.O. ZOGRABIAN \\ ANTIOXIDANTS IN TREATMENT OF CHRONIC RENAL ALLOGRAFT DYSFUNCTION}

ДУ «Національний інститут хірургії та трансплантології імені О.О. Шалімова» НАМН України, Київ SI "National Institute of Surgery and Transplantology named after A. Shalimov" NAMS of Ukraine, Kyiv

Ключові слова: хронічна дисфункція ниркового алотрансплантата, перекісне окислення ліпідів, антиоксидантна система, антиоксиданти

Key words: chronic renal allograft dysfunction, lipid peroxidation, antioxidant system, antioxidants

Резюме. Вступ. Лечение хронической дисфункции почечного аллотрансплантата (ХДПА) остается сложной и нерешенной проблемой современной трансплантологии, поэтому уточнение механизмов развития и усовершенствование методов лечения этого осложнения является актуальним.

Материалы и методы. Проведен сравнительный анализ состояния свободно-радикального окисления y 15 реципиентов с ХДПА и 10 реципиентов со стабильно нормальной функцией трансплантата.

Результаты. В отличие от пациентов с нормальной функцией трансплантата у реципиентов с ХДПА выявлена активация перекисного окисления липидов (ПОЛ) на фоне снижения активности системы антиоксидантной защиты (АОЗ), что дало основание предположить важную роль этих процессов в механизме повреждения трансплантированной почки. Включение препаратов антиоксидантного действия липина и корвитина в комплексную терапию этого состояния у 30 реципиентов способствовало снижению активности процессов ПОЛ, увеличению потенциала системы АОЗ, а также оказывало выраженный ренопротекторный эффект, заключавшийся в улучшении показателей функции почечного трансплантата.

Выводы. Назначение антиоксидантов липина и корвитина способствует замедлению темпов прогрессирования ХДПА.

Summary. Background. Treatment of chronic renal allograft dysfunction (CRAD) presents a serious challenge for modern transplantology, therefore clarifying the mechanisms of development and improving treatment modalities of this complication is of great importance.

Methods. Comparative analysis of peroxidation process activity was carried out in 15 recipients with CRAD and 10 recipients with normal graft function.

Results. Unlike patients with normal graft function an increased activity of lipid peroxidation (LP) and decreased activity of antioxidant system (AOS) were revealed in CRAD recipients. These findings suggest the increased activity of peroxidation process to play an important role in the mechanism of renal allograft damage. Inclusion of antioxidant drugs Lipin and Corvitin in the combined treatment regimen of this condition contributed to reduced activity of LP, increased the capacity of AOS and improved renal allograftt function.

Conclusion. Aantioxidant drugs Lipin and Corvitin contribute to slowing the progression of CRAD.

ВСТУП. Розвиток хронічної дисфункції $\epsilon$ одною с головних причин втрати ниркового алотрансплантата (НАТ) у віддаленому післятрансплантаційному періоді. Основними причинами цього ускладнення є хронічне відторгнення, токсичність інгібіторів кальциневрину, оборотній i de novo гломерулонефрити. Можливим $є$ також розвиток так званої хронічної нефропатії трансплантата (ХНА), яка характеризується на-

Зограб’ян Рубен Овакимович rubenz@mail.ru явністю інтерстиціального фіброзу та канальцевої атрофії при відсутності інших специфічних уражень нирки (2).

Результати декількох досліджень свідчать про можливу участь активації процесів перекісного окислення ліпідів (ПОЛ) в виникненні патології нирок, в тому числі і НАТ (1). Було показано, що розвиток ХНА асоціювався з ростом вільнорадикального окислення, що дозволило припустити значення оксидативного стресу в розвитку та прогресуванні цього патологічного стану [3-8]. Показано, що посилення процесів ПОЛ сприяє потовщенню інтими та медії артеріальних судин, тобто розвитку артеріопатії у реципієнтів НАТ [9]. Ряд досліджень свідчить про перспективнсіть застосування антиоксидантів 3 метою кардіо- та ренопротекції. Однак, переконливих клінічних 
даних щодо їх ефективності при лікуванні хронічної дисфункції ниркового алотрансплантата (ХДНА) в літературі немає [1, 10-11].

МЕТА ДОСЛІДЖЕННЯ. ВизНачити роль процесів вільно-радикального окислення та стану системи антиоксидантного захисту (АО3) у механізмі розвитку та прогресування хронічної дисфункції ниркового алотрансплантата, оцінити ефективність їх корекції з застосуванням препаратів антиоксидантної дії ліпіну і корвітину в комплексній терапії ХДНА.

МАТЕРІАЛИ ТА МЕТОДИ ДОСЛІДЖЕННЯ. 3 метою вивчення значення процесів ПОЛ та AO3 в механізмах розвитку та прогресування ХДНА, ми проаналізували напруженість цих процесів у 15 пацієнтів з ХДНА, яка розвинулася через 12-48 міс після алотрансплантації нирки. Групою порівняння були 10 реципієнтів з стабільно нормальною функцією НАТ у строки після операції, співставні з такими у групі дослідження. Склад груп реципієнтів також практично не відрізнявся за віком і статтю.

Активність процесів ПОЛ оцінювали за концентрацією кінцевого продукту - малонового діальдегіду (МДА) в сироватці крові і еритроцитах. Про стан системи антиоксидантного захисту судили за вмістом церулоплазміна (ЦП) та трансферіна (Тр), активністю основних ферментів антирадикального та антиперекисного захисту: супероксиддисмутази (СОД), каталази (КТ), загальної пероксидазної активності (ЗПА) еритроцитів та вмістом сульфгідрильних груп.

Функцію НАТ оцінювали за величиною діурезу, рівнем креатиніну крові та клубочкової фільтрації.

Також нами проведена оцінка ефективності застосуваня антиоксидантів в комплексній терапії ХДНА. Для цього використовували препарати з вираженою антиоксидантною дією: ліпін у 15 пацієнтів з ХДНА (група 1А) та корвітин у 15 пацієнтів з ХДНА (група 1Б). Групою порівняння були 30 пацієнтів з ХДНА, яким лікування антиоксидантами не проводилося (2 група).

Склад груп реципієнтів НАТ практично не відрізнявся за структурою причин виникнення ХДНА, віком, статтю, рівнем креатинінемії та імуносупресивною терапією. Термін діагности- ки ХДНА, частота і вираженість АГ в основній і порівняльній групах також вірогідно не відрізнялись.

Ліпін призначали в дозі 30 мг/кг, корвітин в дозі 15-20 мг/кг. Препарати вводили довенно, крапельно 1 раз на добу. Тривалість лікування становила 10-14 днів, при погіршенні показників функції НАТ курс лікування повторювали. Період спостереження склав 12 міс.

Усі хворі отримували трикомпонентну імуносупресію: мікроемульсійна форма циклоспорину А (мінімальна концентрація препарату в крові підтримувалася на рівні 70-130 нг/мл), метилпреднізолон (4 мг/доб), мофетіла мікофенолат (1-2 г/доб). Основним діагностичним критерієм ХДНА була стійка тенденція до підвищення рівня креатиніну сироватки крові, обструктивні причини дисфункції виключалися. У 24 пацієнтів спостерігалася артеріальна гіпертензія різного ступеня важкості, з приводу якої застосовували антигіпертензивні препарати. Протеїнурія більше 0,3 г/доб спостерігалася у більшості пацієнтів.

Усі хворі проходили клініко-лабораторне обстеження: оцінювали скарги хворих, загальний аналіз крові та сечі, концентрацію креатиніну та сечовини сироватки крові, швидкість клубочкової фільтрації (ШКФ), рівень артеріального тиску (АТ), добовий діурез.

Ефект антиоксидантів оцінювали за динамікою креатиніну крові, ШКФ, впливом на АТ та динамікою показників ПОЛ та АОС. Про швидкість прогресування ХДНА судили за терміном подвоєння креатиніну в плазмі крові (кінцева точка дослідження) з моменту його першого незворотного підвищення (початкова точка дослідження).

РЕЗУЛЬТАТИ ДОСЛІДЖЕННЯ. ДосЛідження стану пероксидації в організмі реципієнтів 3 ХДНА показало (табл. 1), що у реципієнтів з ХДНА спостерігалося підвищення рівня МДА в сироватці крові майже в 2,7 рази, а в еритроцитах у 1,47 рази порівняно з нормою. У пацієнтів без ХДНА показники пероксидації статистично достовірно від норми не відрізнялися, однак були значно нижчими від таких у пацієнтів з ХДНА. Отримані дані свідчать, що ХДНА розвивається на фоні підвищеної напруженості процесів ПОЛ.

Таблиия 1

Концентрація МДА в крові реципієнтів НАТ у віддаленому післятрансплантаційному періоді залежно від розвитку ХДНА (М \pm m)

\begin{tabular}{|l|c|c|}
\hline \multicolumn{1}{|c|}{ Група обстеження } & \multicolumn{2}{c|}{ Концентрація МДА } \\
\cline { 2 - 3 } & Сироватка крові (мкмоль/л) & Еритроцити (мкмоль/л) \\
\hline Контрольна група $(\mathrm{n}=22)$ & $128 \pm 5$ & $549 \pm 30$ \\
\hline \multirow{2}{*}{ Реципієнти НАТ з ХДНА $(\mathrm{n}=15)$} & $351 \pm 31$ & $811 \pm 44$ \\
& $\mathrm{p} 1<0,05$ \\
\hline \multirow{2}{*}{ Реципієнти НАТ без ХДНА $(\mathrm{n}=10)$} & $172 \pm 32$ & $618 \pm 32$ \\
& $\mathrm{p} 2<0,05$ & $\mathrm{p} 2<0,05$ \\
\hline
\end{tabular}

Примітка: $\mathrm{p}_{1}-$ статистична достовірність різниці у порівнянні з нормою; $\mathrm{p}_{2}-$ статистична достовірність різниці у порівнянні з реципієнтами з ХДНА. 
Активність ферментів антирадикального та антиперекисного захисту в крові реципієнтів НАТ залежно від розвитку ХДНА подана у табл. 2.

Таблиия 2

Активність ферментів антирадикального та антиперекисного захисту в крові реципієнтів НАT (M \pm m)

\begin{tabular}{|c|c|c|c|}
\hline \multirow[b]{2}{*}{ Показники } & \multicolumn{2}{|c|}{ Сироватка крові } & \multirow{2}{*}{$\begin{array}{c}\text { Еритроцити } \\
\text { ЗПА } \\
\text { мкмоль/ хв X } 1 \text { мг Нв }\end{array}$} \\
\hline & $\begin{array}{c}\text { СОД } \\
\text { ум.од./хв х } 1 \text { мг білка }\end{array}$ & $\begin{array}{c}\text { KT } \\
\text { мКат/л }\end{array}$ & \\
\hline Контрольна група (n = 22) & $0,173 \pm 0,009$ & $16,8 \pm 6,2$ & $485 \pm 24$ \\
\hline $\begin{array}{l}\text { Реципієнти НАТ } 3 \text { ХДНА } \\
(\mathrm{n}=15)\end{array}$ & $\begin{array}{l}0,111 \pm 0,015 \\
\mathrm{p}_{1}<0,05\end{array}$ & $\begin{array}{l}26,3 \pm 8,6 \\
\mathrm{p}_{1}>0,05\end{array}$ & $\begin{array}{l}348 \pm 18 \\
\mathrm{p}_{1}<0,05\end{array}$ \\
\hline $\begin{array}{l}\text { Реципієнти НАТ без ХДНА } \\
(\mathrm{n}=10)\end{array}$ & $\begin{array}{c}0,156 \pm 0,007 \\
\mathrm{p}_{2}<0,05\end{array}$ & $\begin{array}{l}24,3 \pm 7,2 \\
\mathrm{p}_{2}>0,05\end{array}$ & $\begin{array}{l}465 \pm 12 \\
\mathrm{p}_{2}<0,05\end{array}$ \\
\hline
\end{tabular}

Примітка: $\mathrm{p}_{1}$ - статистична достовірність різниці у порівнянні з нормою; $\mathrm{p}_{2}-$ статистична достовірність різниці у порівнянні з реципієнтами з ХДНА.

У реципієнтів з ХДНА активність СОД в порівнянні з нормою знижувалася на 55\%, а ЗПА - на 39\%. У реципієнтів без ХДНА показники активності ферментів антирадикального та антиперекисного захисту статистично не відрізнялися від контрольних значень, однак, істотно відрізнялися від таких у пацієнтів з ХДНА, так активність СОД та ЗПА еритроцитів були вірогідно більшими в порівнянні з реципієнтами 3 ХДНА.

Отримані дані показали, що виникнення та прогресування ХДНА у реципієнтів НАТ супроводжується активізацією процесів ПОЛ, що призводить до накопичення токсичних вторинних продуктів ПОЛ в сироватці крові та клітинах. На фоні активації процесів ВРО відбувається зниження активності системи АОЗ, що призводить до гальмування процесів утилізації та знешкодження продуктів ВРО. В той же час у реципієнтів без ХДНА процеси ПОЛ та стан системи АОЗ суттєво не відрізнялися від норми.

Виявлена нами у пацієнтів з ХДНА активація процесів ПОЛ на фоні пригнічення АОС, а також дані про позитивний вплив антиоксидантів на перебіг хронічних захворювань нирок [1, 10], стало теоретичним підгрунтям для застосування цих препаратів в комплексній терапії ХДНА.

Лікування ХДНА необхідно проводити після морфологічної верифікації патологічного процесу (за даними пункційної біопсії), який став причиною дисфункції НАТ, та відповідної корекції імуносупресивної терапії.

У табл. 3 наведено динаміку показників сечовини, креатиніну та ШКФ у процесі лікування антиоксидантами.

Таблиия 3

\section{Динаміка креатиніну, сечовини крові та ШКФ у пацієнтів з ХДНА при лікуванні ліпіном та корвітином}

\begin{tabular}{|l|c|c|c|c|}
\hline \multirow{2}{*}{ Показники } & \multicolumn{2}{|c|}{ Група 1А } & \multicolumn{2}{|c|}{ Група 1Б } \\
\cline { 2 - 5 } & $\begin{array}{c}\text { До } \\
\text { Лікування }\end{array}$ & після лікування & $\begin{array}{c}\text { до } \\
\text { лікування }\end{array}$ & після лікування \\
\hline Сечовина & $14,60 \pm 0,26$ & $11,80 \pm 0,35^{*}$ & $15,20 \pm 0,13$ & $12,20 \pm 0,41^{*}$ \\
\hline Креатинін & $0,261 \pm 0,031$ & $0,168 \pm 0,019^{*}$ & $0,242+0,021$ & $0,171 \pm 0,019^{*}$ \\
\hline ШКФ & $37,40 \pm 1,11$ & $45,60 \pm 1,82^{*}$ & $41,40 \pm 1,03$ & $48,60 \pm 1,22^{*}$ \\
\hline
\end{tabular}

Примітка: * - різниця між показниками до- та після лікування достовірна, $\mathrm{p}<0,05$.

Отримані дані свідчать, що застосування ліпіну та корвітину у пацієнтів з ХДНА сприяло покращенню функції трансплантата: в групі $1 \mathrm{~A}$ зниження рівнів сечовини і креатиніну після лікування склало 19,2 і 35,6\% відповідно, а ШКФ зросла на 22,0\%. В групі 1 Б ці показники склали відповідно 19,7; 29,3 і 17,4\%.

Нами була визначена динаміка ШКФ щомісяця через 1-12 міс після встановлення діагнозу ХДНА. Отримані нами дані показали, що досягнутий внаслідок застосування ліпіну та корвітину позитивний вплив на ШКФ зберіга- ється тільки в межах 2-6 міс: поступово ШКФ знижується і через 2-6 міс іï рівні досягають вихідного рівня, в той час як у групі порівняння ШКФ за 6 міс знижується на 4 мл/хв. Отримані нами дані стали підгрунтям для призначення повторних курсів антиоксидантів через 2-6 міс.

Подвоєння рівня креатиніну за 12 міс спостереження було констатовано у трьох хворих групи 1А (20,0\%) та чотирьох хворих групи 1Б $(25,0 \%)$ і у 12 реципієнтів НАТ порівняльної групи $(40,0 \%, \mathrm{p}<0,05)$. 
Таким чином, можна констатувати виражений ренопротекторний ефект корвітину та ліпіну у комплексній терапії ХДНА.

Вивчення динаміки АТ у пацієнтів трьох груп (табл. 4) показало, що лікування корвіти- ном супроводжується тенденцією до зниження AT, в той час як гіпотензивної дії ліпіну констатовано не було.

Таблиия 4

Динаміка середнього АТ у пацієнтів з ХДНА при застосуванні ліпіну та корвітину

\begin{tabular}{|l|c|c|c|}
\hline \multirow{2}{*}{\multicolumn{1}{|c|}{ Підгрупи реципіснтів }} & \multicolumn{3}{|c|}{ АТ середній, мм рт. ст. } \\
\cline { 2 - 4 } & До лікування & Після лікування & Р \\
\hline IА $(\mathrm{n}=15)$ & $112,3 \pm 1,3$ & $111,7 \pm 2,2$ & $>0,05$ \\
\hline ІБ $(\mathrm{n}=15)$ & $112,1 \pm 2,8$ & $104,2 \pm 2,3$ & $>0,05$ \\
\hline Гр. порівняння $(\mathrm{n}=30)$ & $111,4 \pm 3,7$ & $112,8 \pm 3,5$ & $>0,05$ \\
\hline
\end{tabular}

Таким чином, отримані дані показали, що застосування ліпіну та корвітину в комплексній терапії ХДНА дає можливість загальмувати їі прогресування, стабілізувати ШКФ та АТ.
Ми також оцінили вплив корвітину та ліпіну на активність процесів ПОЛ та стан АОС (табл. 5).

\section{Концентрація МДА в крові реципієнтів НАТ до- та після лікування АО (М \pm m)}

\begin{tabular}{|l|c|c|}
\hline \multicolumn{1}{|c|}{ Група обстеження } & \multicolumn{2}{|c|}{ Концентрація МДА } \\
\cline { 2 - 3 } & $\begin{array}{c}\text { Сироватка крові, } \\
\text { мкмоль/л }\end{array}$ & $\begin{array}{c}\text { Еритроцити, } \\
\text { мкмоль/л }\end{array}$ \\
\hline $\begin{array}{l}\text { Реципієнти НАТ з ХДНА до лікування }(\mathrm{n} \\
=18)\end{array}$ & $351 \pm 31$ & $811 \pm 44$ \\
\hline $\begin{array}{l}\text { Реципієнти НАТ з ХДНА після лікування } \\
\text { ліпіном (n=8) }\end{array}$ & $\begin{array}{l}180 \pm 42 \\
\mathrm{p}<0,05\end{array}$ & $\begin{array}{l}600 \pm 30 \\
\mathrm{p}<0,05\end{array}$ \\
\hline $\begin{array}{l}\text { Реципієнти НАТ з ХДНА після лікування } \\
\text { корвітином (n=10) }\end{array}$ & $\begin{array}{l}160 \pm 17 \\
\mathrm{p}<0,05\end{array}$ & $\begin{array}{l}580 \pm 42 \\
\mathrm{p}<0,05\end{array}$ \\
\hline
\end{tabular}

Примітка: $\mathrm{p}$ - статистична достовірність різниці у порівнянні з рівнем до лікування.

Отримані дані показали, що проведене лікування антиоксидантами позитивно впливає на напруженість процесів ПОЛ. Зміни, які відбуваються, є статистично вірогідними. Показники ПОЛ наближаються до норми та вірогідно не відрізняються від неї.

Активність ферментів антирадикального та антиперекисного захисту в крові реципієнтів НАТ з ХДНА до- та після лікування антиоксидантами подана у табл. 6.

Активність ферментів антирадикального та антиперекисного захисту в крові реципієнтів НАТ в динаміці лікування антиоксидантами (M \pm m)

\begin{tabular}{|l|c|c|c|}
\hline \multirow{2}{*}{\multicolumn{1}{|c|}{ Показники }} & \multicolumn{2}{|c|}{ Сироватка крові } & Еритроцити \\
\cline { 2 - 4 } & $\begin{array}{c}\text { СОД } \\
\text { ум.од./хв х 1мг білка }\end{array}$ & $\begin{array}{c}\text { КТ } \\
\text { мкат/л }\end{array}$ & $\begin{array}{c}\text { ЗПА } \\
\text { мкмоль/хв х 1мг Нв }\end{array}$ \\
\hline $\begin{array}{l}\text { Реципієнти НАТ 3 ХДНА } \\
\text { до лікування }(\mathrm{n}=18)\end{array}$ & $0,111 \pm 0,015$ & $26,33 \pm 8,60$ & $348 \pm 18$ \\
\hline $\begin{array}{l}\text { Реципієнти НАТ з ХДНА } \\
\text { після лікування ліпіном }(\mathrm{n}=8)\end{array}$ & $\begin{array}{c}0,165 \pm 0,017 \\
\mathrm{p}<0,05\end{array}$ & $\begin{array}{c}20,5 \pm 8,4 \\
\mathrm{p}>0,05\end{array}$ & $\begin{array}{c}420 \pm 17 \\
\mathrm{p}<0,05\end{array}$ \\
\hline $\begin{array}{l}\text { Реципієнти НАТ з ХДНА } \\
\text { після лікування корвітином }(\mathrm{n}=10)\end{array}$ & $\begin{array}{c}0,150 \pm 0,011 \\
\mathrm{p}<0,05\end{array}$ & $\begin{array}{c}29,3 \pm 9,6 \\
\mathrm{p}>0,05\end{array}$ & $\begin{array}{c}443 \pm 14 \\
\mathrm{p}<0,05\end{array}$ \\
\hline
\end{tabular}

Примітка: $\mathrm{p}$ - статистична достовірність різниці у порівнянні з показниками до лікування. 
Наші дані свідчать про істотне покращення усіх показників активності ферментів антирадикального та антиперекисного захисту в крові після проведеного курсу лікування ліпіном та корвітином.

ВИСНОВКИ. Таким чином, результати проведеного дослідження свідчать про те, що активація процесів вільно-радикального окислення може відігравати суттєву роль в розвитку ХДНА. Застосування препаратів антиоксидантної дії ліпіну і корвітину в комплексній терапії цього ускладнення зменшує напруженість процесів ПОЛ, збільшує потенціал системи антиоксидантного захисту, покращує показники функції НАТ: ШКФ зростала на 17,4-22,0\%, знижувалися рівні сечовини (на 19,2-19,7\%) та креатиніну (на 29,3-35,6\%).

Корвітин також сприяє нормалізації артеріального тиску. Нажаль, позитивний ефект антиоксидантів носить лише тимчасовий характер і зберігається тільки в межах 6 міс: поступово ШКФ знижується і через 2-6 міс досягає рівня до лікування. Тобто доцільно призначати повторні курси антиоксидантів не рідше ніж один раз у 6 місяців. Отримані нами результати показали також здатність ліпіну та корвітину уповільнювати темпи прогресування ХДНА. Таким чином, можна констатувати виражений ренопротекторний ефект корвітину та ліпіну у комплексній терапії ХДНА.

\section{ЛІТЕРАТУРА:}

1. Король Л. В. Оксидативные процессы в поражении клеточных мембран при гломерулонефрите и их коррекция с помощью липосомального препарата «Липин» / Л. В. Король, Г. Г. Никулина // Український журнал нефрології та діалізу. 2005. - № 3. - C. 31 - 33.

2. Fadili $W$. Chronic renal allograft dysfunction: risk factors, immunology and prevention / W. Fadili, A.M. Habib, I. Laouad // Arab Journal of Nephrology and Transplantation. - 2013. - V. 6. - N 1. - P. 45-50.
3. Oxidative Stress and chronic allograft nephropathy / H. Ha, J. Park, Y. S. Kim, H. Endou // Yonsei Medical Journal. - 2004. - Vol. 45, N 6. - P. 1049 - 1052.

4. Advanced glycation end products and oxidative stress are increased in chronic allograft nephropathy / D. S. C. Raj, C. Lim, M. Levi [et al.] // Am. J. Kidney Dis. - 2004. - Vol. 43. - P. $154-160$.

5. Oxidative Stress and chronic allograft nephropathy / H. Ha, J. Park, Y. S. Kim, H. Endou // Yonsei Medical Journal. - 2004. - Vol. 45, N 6. - P. 1049 - 1052.

6. Advanced glycation end products and oxidative stress are increased in chronic allograft nephropathy / D. S. C. Raj, C. Lim, M. Levi [et al.] // Am. J. Kidney Dis. - 2004. - Vol. 43. - P. $154-160$.

7. Oxidative stress and inflammation in long-term renal transplanted hypertensives / S. Cottone, A. Palermo, F. Vaccaro [et al.] // Clin. Nephrol. - 2006. - Vol. 66, N 1. - P. $32-38$.

8. Ramos L. F. Oxidative stress and inflammation are associated with adiposity in moderate to severe CKD / L. F. Ramos, A. Shintani, T. A. Ikizler // J. Am. Soc. Nephrol. - 2008. - V. 19. - P. 593 - 599.

9. Prediabetic states, subclinical atheromatosis, and oxidative stress in renal transplant patients / J. M. Osorio, C. Ferreyra, A. Perez [et al.] // Transplant Proc. 2009. - Vol. 41, N 6. - P. 2148 - 2150.

10. Joo D. J. Change in serum lipid peroxide as an oxidative stress marker and its effects on kidney function after successful kidney transplantation / D. J. Joo, K. H. Huh, Y. Cho // Transplant. Proc. - 2010. - Vol. 42, N 3. - P. $729-732$.

11. Loong C. C. Antioxidant supplementation may improve renal transplant function: a preliminary report / C. C. Loong, Y. H. Chang, T. H. Wu // Transplant. Proc. - 2004. - Vol. 36, N 8. - P. 2438 - 2439.

12. Mitochondria-targeted antioxidant peptide SS31 prevents hypoxia/reoxygenation-induced apoptosis by down-regulating p66Shc in renal tubular epithelial cells / W.Y. Zhao, S. Han, L. Zhang [et al] / Cell. Physiol. Biochem. - 2013. - 32, N 3. - P. 591-600.

Надійшла до редакції 04.02.2013 Прийнята до друку 14.02.2014 